\title{
The illusory nature of ontological status and its implications for legal, moral and social organisation - RETRACTION
}

Dr Anthony Amatrudo

https://doi.org/10.1017/S1744552308001031 Published online by Cambridge University Press 17 July 2008

It has been brought to our attention that the above article (Amatrudo, D. (2008)) reuses sections of Hans Kribbe, Corporate Personality: A Political Theory of Association (2003) without permission or acknowledgement and has therefore been retracted. The author acknowledges this with regret.

\section{References}

Amatrudo D (2008) The illusory nature of ontological status and its implications for legal, moral and social organisation. International Journal of Law in Context 4, 63-77. doi:10.1017/S1744552308001031

Kribbe Hans (2003) Corporate personality: A political theory of association. 1-295. (PhD thesis, London School of Economics and Political Science (United Kingdom)). http://etheses.lse.ac.uk/id/eprint/2659

\footnotetext{
Cite this article: Amatrudo A (2019). The illusory nature of ontological status and its implications for legal, moral and social organisation - RETRACTION. International Journal of Law in Context 15, 103-103. https://doi.org/10.1017/ S1744552318000307 